Bangladesh J. Bot. 47(3): 451-458, 2018 (September)

\title{
DETERMINATION OF CORRELATION BETWEEN PLANT DISTRIBUTION AND ECOLOGICAL FACTORS IN NAROWAL DISTRICT PUNJAB, PAKISTAN
}

\author{
Arifa Zereen*, Sheikh SAEed Ahmad ${ }^{1}$, ZAheEr-Ud-Din Khan ${ }^{2}$ \\ and Almas Jahan ${ }^{3}$ \\ University of Education Bank Road Campus, Lahore, Pakistan \\ Keywords: Correlation, Multivariate techniques, Soil, Water
}

\begin{abstract}
In order to study correlation between ecological factors and vegetation distribution, multivariate analysis was undertaken. Thirty four plant families represented by 59 species were recorded. For classifying the plant communities TWINSPAN (Two Way Indicator Species Analysis) software program was used. After analysis plants were categorized into two large (major) and six small (sub) communities. Water and soil samples were analyzed for $\mathrm{pH}$, EC, soil colour and soil water content. Canonical correspondence analysis (CCA) was employed to correlate species distribution pattern to environmental factors. Results showed that despite many variables being strongly correlated, they were of little value in grouping together of species. However, soil $\mathrm{pH}$ and electrical conductivity (EC) had effects on distribution of vegetation.
\end{abstract}

\section{Introduction}

Narowal is a district of province Punjab, Pakistan and its total area is about $2337 \mathrm{~km}^{2}$. It lies at $32^{\circ} 13^{\prime} 44^{\prime \prime} \mathrm{N}$ and $74^{\circ} 57^{\prime} 1^{\prime \prime} \mathrm{E}$ and is surrounded by Sialkot district, Jammu and Kashmir, Gurdaspur district and Sheikhupura district. Its fertile loamy soil has a good proportion of silt which makes it suitable for growing various crops. Narowal is located in the sub humid climatic zone of Pakistan.

In order to conserve a habitat for longer period of time and classify the flora of that area biological assessment is employed (Shahbaz et al. 2007). TWINSPAN technique was applied for analysis of floral data (Graveson 2009). Ayub et al. (2017) classified the herbaceous vegetation in a valley of district Zhob, by employing TWINSPAN. In another study at waste landfills of Seoul Metropolitan area TWINSPAN analysis identified 275 species belonging to 63 families of vascular plants and grouped them into 6 communities (Kim 2013).

CCA technique is a combination of Correspondence Analysis and Regression Method (Braak 1986). Distribution of plant communities is influenced by multiple of environmental factors, hence CANOCO program possesses the capacity to consider and manipulate these influences (Kent and Coker 1995, Kashian et al. 2003). Ayub et al. (2017) used CCA to study the distribution of plant species under the influence of edaphic factors at Shinghar Valley, district Zhob. They found zinc and organic matter of the soil were playing most important role in the distribution pattern of vegetation. Zereen et al. (2017) worked in district Sahiwal, Punjab and used CCA to develop vegetation, water and soil relationships and associations. Main purpose of present survey was to document the flora of Narowal district that was not studied before. The effect of edaphic and hydrological factors operating in the study area on the distribution of plant communities was estimated by using multivariate techniques i.e., TWINSPAN and CCA.

*Author for correspondence: <arifazereen@gmail.com>, <arifazereen@ yahoo.com>. ${ }^{1}$ Fatima Jinnah Women University, the Mall Rawalpindi, Pakistan. ${ }^{2}$ Department of Botany, GC University, Lahore, Pakistan. ${ }^{3}$ University of Education Bank Road Campus, Lahore, Pakistan. 


\section{Materials and Methods}

Narowal is one of the districts of Province Punjab, Pakistan. Its land comprised of piedmont plains and adjoining plains of River Ravi, Deg, Bias and Basantar. Its soils are silty and loamy, suitable for cultivation of a variety of crops. This district is divided into three tehsils namely, Narowal that lies at $32^{\circ} 21^{\prime} \mathrm{N}$ and $74^{\circ} 54^{\prime} \mathrm{E}$, Shakargarh that lies at $32^{\circ} 15^{\prime} 46^{\prime \prime} \mathrm{N}$ and $75^{\circ} 9^{\prime} 30^{\prime \prime} \mathrm{E}$ and Zafarwal that lies at $32^{\circ} 21^{\prime} 0 \mathrm{~N}$ and $74^{\circ} 54^{\prime} 0 \mathrm{E}$. From each tehsil at least three study sites were selected.

Sampling and data collection of vegetation were carried out at flowering stage, during spring season i.e., February to April. Forty quadrats of different sizes after Braun-Blanquet method were used. Sampled plant species were identified by consulting literature and flora of Pakistan (Nasir and Ali 1970-1989; Ali and Nasir 1990-1992 and Ali and Qaisar 1992-2010). Plant cover and frequency values were recorded (Kent and Coker 1992).

Sampling of soil was carried out from each quadrat and its texture, colour, moisture content, $\mathrm{pH}$ and EC were analyzed in laboratories of Soil Survey of Punjab. Similarly water table depth, $\mathrm{pH}$ and EC were recorded for water samples (Allen et al. 1974).

The phytosociological statistics were analyzed by TWINSPAN software that identified the major and sub plant communities at the study site. CCA was used to establish floristicenvironment relationship. Matrix sheets prepared in Microsoft Excel were run in CANOCO and species scatter biplot graph was obtained. Fig. 1 is depicting the sequence of steps followed in the study.

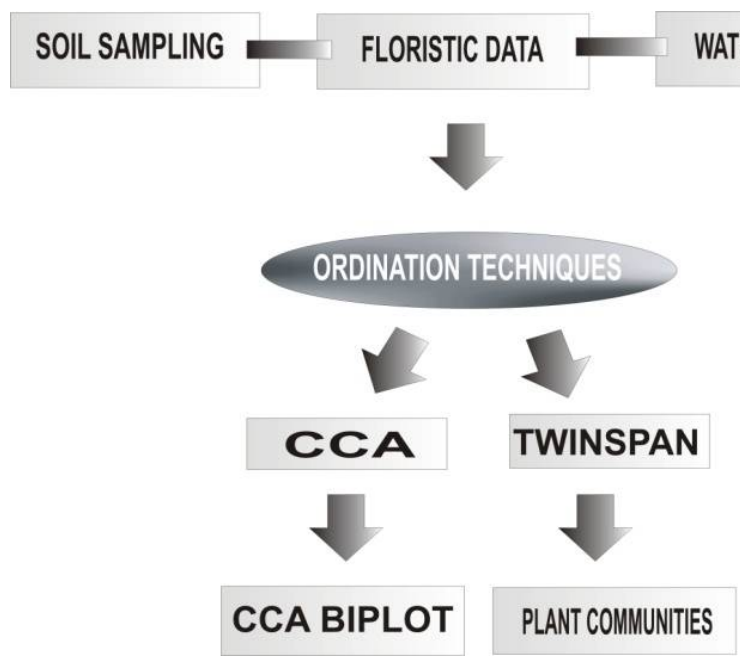

Fig. 1. Flow chart of methodology.

\section{Results and Discussion}

Percentage cover values of 59 species recorded out of 40 quadrats at Narowal district were used for analysis in TWINSPAN program and two major and six sub-communities were identified. All the communities were named on most dominant species with respect to their cover values (Fig. 2). Table 1 embodies the abbreviations for plant species used in Figs 2 and 3.

Major community 1: Oxalis corniculata and Solanum nigrum community had highest cover values in the area. It had two sub-communities. 
Sub-community Dalbergia sissoo and Ricinus communis: It was a minor community comprised of seven species. Plants part of this community appeared on margins of crop fields, abandoned plots and edges of road leading from Narowal to Pasrur. Data for this plant community were recorded from 24 quadrats. This study site was mostly surrounded by wheat fields.

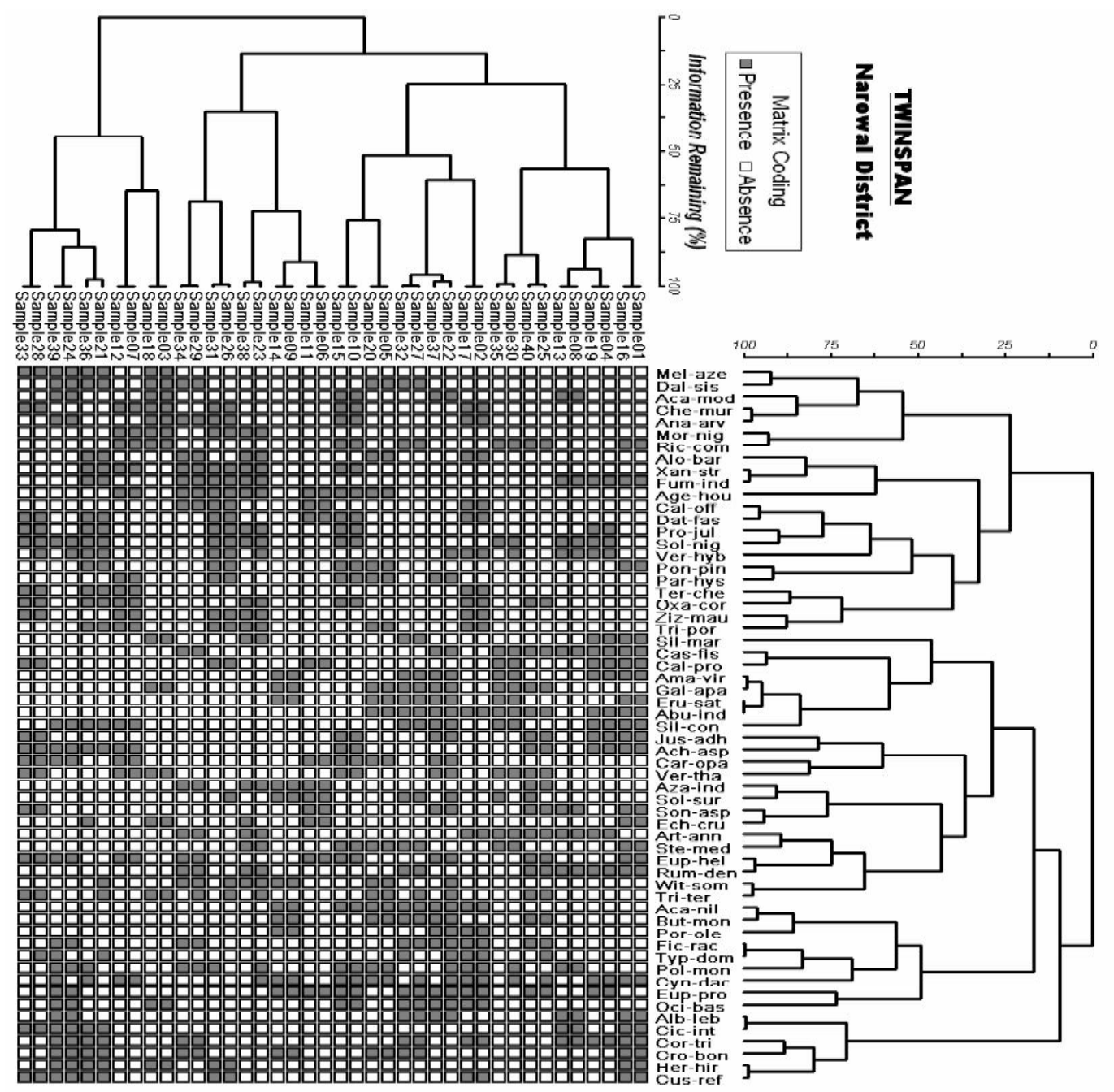

Fig. 2. TWINSPAN analysis of floristic data.

Sub-community Solanum nigrum and Oxalis corniculata: Dominant species of this community were same as of major community 1 . It was large group compared to previous one and existed on margins of cultivated fields in Zafarwal village of Tehsil Shakargarh. Coexistence of Solanum nigrum and Oxalis corniculata indicates their similar ecological requirements and characteristics. This group showed presence in 31 quadrats and high cover values for two major species. 
Table 1. Abbreviations for plant species presented in Figs 2 and 3.

\begin{tabular}{|c|c|c|c|}
\hline Sr. No. & Species & Families & Abbreviations \\
\hline 1. & Abutilon indium $\mathrm{L}$. & Malvaceae & Abu-ind \\
\hline 2. & Acacia modesta Wall. & Fabaceae & Aca-mod \\
\hline 3. & Acacia nilotica (L.) Delile & Fabaceae & Aca-nil \\
\hline 4. & Achyranthes aspera $\mathrm{L}$. & Amranthaceae & Ach-asp \\
\hline 5. & Ageratum houstonianum Mill. & Asteraceae & Age-hou \\
\hline 6. & Albizia lebbeck (L.) Benth. & Mimosaceae & $A l b-l e b$ \\
\hline 7. & Aloe barbadensis (L.) Burm.f. & Asphodelaceae & Alo-bar \\
\hline 8. & Amaranthus viridis $\mathrm{L}$. & Amaranthaceae & Ama-vir \\
\hline 9. & Anagallis arvensis L. & Primulaceae & Ana-arv \\
\hline 10. & Artemisia аппиа $\mathrm{L}$. & Asteraceae & Art-ann \\
\hline 11. & Azadirachta indica Adr.Juss & Meliaceae & Aza-ind \\
\hline 12. & Butea monosperma (Lain.) Taubert & Papilonaceae & But-mon \\
\hline 13. & Calotropis procera (Ait.) Ait.f. & Asciepiadaceae & Cal-pro \\
\hline 14. & Cassia fistula $\mathrm{L}$ & Fabaceae & Cas-fis \\
\hline 15. & Calendula officinalis L. & Asteraceae & Cal-off \\
\hline 16. & Chenopodium murale $\mathrm{L}$. & Chenopodiaceae & Che-mur \\
\hline 17. & Cynodon dactylon (L.) Pers. & Poaceae & Cyn-dac \\
\hline 18. & Dalbergia sissoo Roxb. & Papilonaceae & Dal-sis \\
\hline 19. & Datura fastuosa $\mathrm{L}$. & Solanaceae & Dat-fas \\
\hline 20. & Carissa opaca Stapf ex Haines & Apocynaceae & Car-apa \\
\hline 21. & Cichorium intybus L. & Asteraceae & Cis-int \\
\hline 22. & Corchorus trilocularis L. & Tiliaceae & Cor-tri \\
\hline 23. & Croton bonplandianum Baill & Convolvulaceae & Cro-bon \\
\hline 24. & Cuscuta reflexa Roxb. & Cuscutaceae & Cus-ref \\
\hline 25. & Echinochloa crusgalli (L.) P.Beauv. & Poaceae & Ech-cru \\
\hline 26. & Euphorbia prostrata Linn. & Asteraceae & Ecl-pro \\
\hline 27. & Eruca sativa Mill. & Brassicaceae & Eru-sat \\
\hline 28. & Euphorbia helioscopia L. & Euphorbiaceae & Eup-hel \\
\hline 29. & Ficus racemosa $\mathrm{L}$. & Moraceae & Fic-rac \\
\hline 30. & Fumaria indica (Hausskn.) Pugsley & Fumaraceae & Fum-ind \\
\hline 31. & Galium aparine $\mathrm{L}$. & Rubiaceae & Gal-apa \\
\hline 32. & Herniaria hirsute L. & Illecebraceae & Her-hir \\
\hline 33. & Justicia adhatoda $\mathrm{L}$. & Acanthaceae & Jus-adh \\
\hline 34. & Melia azedarach $\mathrm{L}$. & Meliaceae & Mel-aze \\
\hline 35. & Morus nigra $\mathrm{L}$. & Moraceae & Mor-nig \\
\hline 36. & Ocimum basilicum $\mathrm{L}$. & Labiatae & Oci-bas \\
\hline 37. & Oxalis corniculata $\mathrm{L}$. & Oxalidaceae & Oxa-cor \\
\hline 38. & Parthenium hysterophorus Linn. & Asteraceae & Par-hys \\
\hline
\end{tabular}




\begin{tabular}{|c|c|c|c|}
\hline 39. & $\begin{array}{l}\text { Polypogon monspeliensis (L.) } \\
\text { Desfontaines. }\end{array}$ & Poaceae & Pol-mon \\
\hline 40. & Pongamia pinnata (L.) Pierre. & Fabaceae & Pon-pin \\
\hline 41. & Portulaca oleracea L. & Aizoaceae & Por-ole \\
\hline 42. & Prosopis juliflora (Swartz) DC & Fabaceae & Pro-jul \\
\hline 43. & Ricinus communis L. & Euphorbiaceae & Ric-com \\
\hline 44. & Rumex dentatus $\mathrm{L}$. & Polygonaceae & Rum-den \\
\hline 45. & Silene conoidea $\mathrm{L}$. & Caryophyllaceae & Sil-con \\
\hline 46. & Silybum marianum (L.) Gaertn. & Asteraceae & Sil-mar \\
\hline 47. & Solanum nigrum $\mathrm{L}$. & Solanaceae & Sol-nig \\
\hline 48. & Solanum surattense Burm.f & Solanaceae & Sol-sur \\
\hline 49. & Sonchus asper L. & Asteraceae & Son-asp \\
\hline 50. & Stellaria media (L.) Will & Caryophyllaceae & Ste-med \\
\hline 51. & Terminalia chebula Retzius & Combretaceae & Ter-che \\
\hline 52. & Trianthema portulacastrum $\mathrm{L}$. & Aizoaceae & Tri-por \\
\hline 53. & Tribulus terrestris $\mathrm{L}$. & Zygophyllaceae & Tri-ter \\
\hline 54. & Typha domingensis Pers & Typhaceae & Typ-dom \\
\hline 55. & Verbascum Thapsus L. & Scrophulariaceae & Ver-tha \\
\hline 56. & Veronica hybrida $\mathrm{L}$. & Plantaginaceae & Ver-hyb \\
\hline 57. & Withania somnifera (L.) Dunal. & Solanaceae & Wit-som \\
\hline 58. & Xanthium strumarium L. & Asteraceae & Xan-str \\
\hline 59. & Ziziphus mauritiana Lam. & Rhamnaceae & Ziz-mau \\
\hline
\end{tabular}

Table 2. Chemical and Physical Properties of Soils from Narowal Districts.

\begin{tabular}{|c|c|c|c|c|c|c|c|c|c|}
\hline \multirow{2}{*}{$\begin{array}{l}\text { Sl. } \\
\text { No. }\end{array}$} & \multirow[t]{2}{*}{ District } & \multicolumn{3}{|c|}{ Physical properties } & \multirow{2}{*}{$\begin{array}{l}\text { Soil } \\
\text { textural } \\
\text { class }\end{array}$} & \multirow{2}{*}{$\begin{array}{l}\text { Soil color } \\
\text { (Dry soil) }\end{array}$} & \multirow[b]{2}{*}{$* \mathrm{pH}$} & \multirow[b]{2}{*}{$* \mathrm{EC} \mathrm{dS} / \mathrm{m}$} & \multirow{2}{*}{$\begin{array}{l}\text { *Water } \\
\text { content } \\
(\%)\end{array}$} \\
\hline & & $\begin{array}{c}\text { Sand } \\
(\%)\end{array}$ & $\begin{array}{l}\text { Silt } \\
(\%)\end{array}$ & $\begin{array}{l}\text { Clay } \\
(\%)\end{array}$ & & & & & \\
\hline 1 & Narowal & 49 & 37 & 14 & Loam & $\begin{array}{c}\text { Brown } \\
(10 \text { YR.5/3) }\end{array}$ & 7.6 & 2.5 & 12 \\
\hline
\end{tabular}

*Mean value.

Table 3. Chemical characteristics of water from Narowal District.

\begin{tabular}{lllccc}
\hline Sl. No. & District & Source & $* \mathrm{pH}$ & ${ }^{*} \mathrm{EC} \mathrm{dS} / \mathrm{m}$ & Water Table $(\mathrm{ft})$ \\
\hline 1 & Narowal & Hand pump & 7.40 & 0.69 & $60-65$ \\
\hline
\end{tabular}

*Mean value.

Major community 2: Cynodon dactylon and Euphorbia helioscopia are prominent species of this community because of its greater frequency and cover values. It had four sub communities.

Sub-community Silene conoidea and Abutilon indicum: This community was growing at abandoned pieces of land besides the canal in Ahmadabad Town. Silene conoidea and Abutilon indicum were dominant species here. The group appeared in 33 quadrats with high cover values e.g., Silene conoidea $41 \%$ and Abutilon indicum $39 \%$. 
Sub-community Achyranthes aspera and Euphorbia helioscopia: This community existed on unused lands, field edges and road margins throughout Shakargarh. Microclimate requirements by dominant species appeared similar. So the sub-community occurred in quadrats fulfilling their microclimatic requirements.

Sub-community Cynodon dactylon and Euphorbia prostrata: The plant species of this community existed together because of similar microhabitat and ecological requirements. Plants of this community existed throughout the study area i.e., along roads, crop fields and abandoned lands where Muridkey road links with Pasrur road. The percentage cover values of dominant species were relatively higher i.e., Cynodon dactylon $51.4 \%$ and Euphorbia prostrata $46 \%$. Further important plants of this community were Ficus racemosa, Acacia nilotica, Ocimum basilicum and Polypogon monspeliensis.

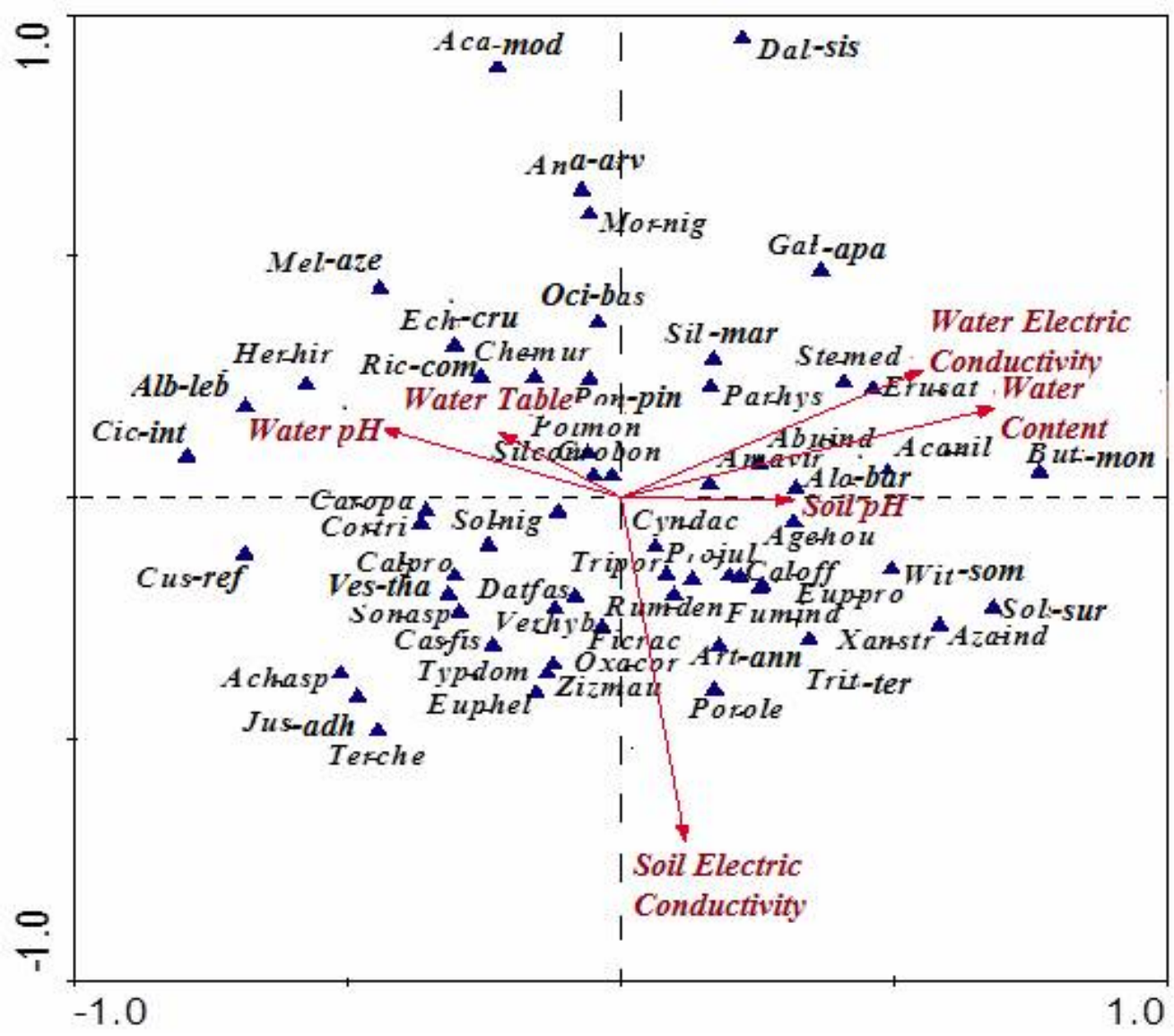

Fig. 3. CCA biplot graph of species and ecological parameters.

Sub-community Croton bonplandianus and Corchorus trilocularis: This small community was recorded from quadrats studied at Aliabad village, Shakargarh. This area is highly disturbed. The sub- community comprised of six, mostly herbaceous species i.e., Cuscuta reflexa, Herniaria hirsuta, Croton bonplandianum and Cichorium intybus. 
CCA biplot for species and ecological parameters: In CCA biplot graph, for plant distribution with reference to ecological parameters, majority of factors exhibited strong correlation with each other but did not perform any significant part in plant grouping. In Fig. 3 soil EC has longest arrow while water EC and water content were having equal length arrows. Arrows for soil $\mathrm{pH}$, water EC, and water content showed positive correlation as their arrows pointing in same direction, while arrows for water $\mathrm{pH}$ and water table were directed oppositely exhibiting negative correlation with respect to other ecological parameters. Same reaction of soil $\mathrm{pH}$ to water EC has been observed in the studies carried out by Gulshad et al. (2016) and Ahmad et al. (2013). Parthenium hysterophorus, Setaria intermedia and Eruca sativa were being more affected by electrical conductivity (EC) of water. Biplot graph for plants and ecological parameters presented existence of strong relationship between species distribution and environmental factors along axis 1. Water content appears to play role in assemblage of Acacia nilotica and Butea monosperma as they exist near water content arrow. Silene conoidea and Polypogon monspeliensis showed association with water table. While reporting results of their studies Gulshad et al. (2016) reported that $\mathrm{pH}$, organic matter content and soil moisture content play key role in determining plant abundance and distribution. Various other studies also proved that plant frequency and cover in an area depends on soil quality (Urooj et al. 2016, Yuce and Göunlül 2016). Results of water and soil samples collected from study area are presented in Tables 2 and 3.

Vegetation cover is very important as it performs many important functions like preventing soil erosion, providing habitat and food for wild life, pollutant absorption, having esthetic value etc. In order to maintain resources on sustainable basis strong management is required for preservation and protection of vegetation of the area. Over exploitation of natural resources should be avoided.

\section{References}

Ahmad SS, Nawaz M and Khan SM 2013. Evaluating the effects of soil pH and moisture on the plant species of Changa Manga Forest using Van Dobben Circles. Middle-East J. Sci. Res. 17 (10): 1405-1411.

Allen SE 1974. Chemical analysis of ecological materials. Blackwell scientific publications; Oxford (London). 565.

Ali SI and Nasir YJ 1990-92. Flora of Pakistan. Nos. 191-193. Department of Botany, University of Karachi and National Herbarium, PARC, Islamabad.

Ali SI and Qaiser M 1992- 2010. Flora of Pakistan. Nos. 194-208. Department of Botany, University of Karachi and National Herbarium,PARC, Islamabad.

Ayub A, Ahmad SS, Erum S and Butt A 2017. Pedological and floral assessment of Shinghar valley (District Zhob) through multivariate tools. J. Ani. and Plant Sci. 27(3): 953-960.

Braak CJFT 1986. Canonical correspondence analysis: A new Eigen vector technique for multivariate direct gradient analysis. Ecol. 67: 1167-79.

Gulshad K, Ahmad SS, Bashir H and Erum S 2016. Differential responses of vegetation along effective soil gradients in Mughal Garden Wah, Pakistan. Intl. J. Eco. Environ. Geol. 7(1): 36-41.

Graveson R 2009. The classification of the vegetation of Saint Lucia FCG (Finnish Consultancy Group) International Ltd. Helsinki, Finland.

Kashian DM, Barnes BV and Walker WS 2003. Ecological species groups of land form- level ecosystems dominated by Jack Pine in northern Lower Michigan, USA. Plant Ecol. 166: 75-91.

Kent M and Coker P 1995. Vegetation description and analysis. 2nd ed. John Wiley, Chichester.

Kent M and Coker P 1992. Vegetation description and analysis. 1st ed. Bilhaven Press, London.

Kim KD 2013. Vegetation dynamics on waste landfills in the Seoul metropolitan area. Int. J. Env. Res. 7(3):801-806. 
Nasir E and Ali SI 1970-89. Flora of Pakistan. No. 1-190. National Herbarium, PARC, Islamabad and Department of Botany, University of Karachi, Pakistan.

Shahbaz B, Ali Tand Suleri AQ 2007. A critical analysis of forest policies of Pakistan: Implications for sustainable livelihoods. Mitigation and Adaptation Strategies for Global Change. 12(4): 441-453.

Urooj R, Ahmad SS, Ahmad MN, Ahmad H and Nawaz M 2016. Ordination study of vegetation analysis around wetland area: A case study of Mangla Dam, Azad Kashmir, Pakistan. Pakistan J. Bot. 48(1):115119.

Yuce AM and Gönülol A 2016.Evaluation of the relationship between epiphytic diatoms and environmental parameters with the Canonical Correspondence Analysis (CCA). Pak. J. Bot. 48(4): 1723-1730.

Zereen A Jahan A, Ahmad SA and Khan ZUD 20178. Floral and edaphic data recorded from Sahiwal District, Pakistan analyzed by multivariate techniques. Biologia (Pakistan). 64(1): 173-177.

(Manuscript received on 1 March, 2018; revised on 6 May, 2018) 